\title{
Biotic exchange from movement of 'static' maritime structures
}

\author{
Josephine C. Iacarella · Ian C. Davidson · Anya Dunham
}

Received: 23 July 2018/ Accepted: 21 November 2018/Published online: 30 November 2018

(C) The Author(s) 2018

\begin{abstract}
Coastal infrastructure provides extensive habitat for marine nonindigenous species ("NIS"), especially biofouling species. Ecosystem transplants can arise when static maritime structures ("SMS") are relocated under slow towing speeds following long periods of biofouling accumulation. Translocations of SMS occur more often than acknowledged and represent a high-risk vector of marine NIS that is largely overlooked and unregulated. We compiled geolocations and movement patterns for oil platforms, derelict/obsolete vessels, barges, dry docks, floating lodges, homes and docks, aquaculture gear and buoys for the NE Pacific coast. We related these data to NIS richness within the region and to global examples of SMS movement. Our review and synthesis of SMS, paired with biofouling surveys before and after dock towing events, reveal the growing NIS vector
\end{abstract}

Anya Dunham: previously published as A. Epelbaum.

Electronic supplementary material The online version of this article (https://doi.org/10.1007/s10530-018-1888-8) contains supplementary material, which is available to authorized users.

J. C. Iacarella $(\bowtie) \cdot A$. Dunham

Fisheries and Oceans Canada, Pacific Biological Station, 3190 Hammond Bay Rd, Nanaimo, BC V9T 6N7, Canada e-mail: Josephine.Iacarella@dfo-mpo.gc.ca

I. C. Davidson

Smithsonian Environmental Research Centre, 647

Contees Wharf Road, Edgewater, MD 21037, USA opportunities resulting from sprawling coastal infrastructure. As coastal development continues apace in the Anthropocene, this emerging management challenge will require strong frameworks and workable solutions for a global issue that currently lacks incentives to prevent species transfers and invasions.

Keywords Nonindigenous species · Marine · Artificial structures $\cdot$ Spread $\cdot$ Biofouling $\cdot$ Vectors

\section{Introduction}

Extensive coastal and offshore development has led to worldwide marine urbanization-an expansion of artificial structures into marine waters-and creation of habitat for both native and nonindigenous species ("NIS") (Firth et al. 2016; Bishop et al. 2017). Coastal populations generate demand for marine infrastructure that is increasing at rates of between $3.7 \%$ and $28.3 \%$ per year (Duarte et al. 2013). NIS that inhabit biofouling communities are highly prevalent on these artificial structures (Simkanin et al. 2012; Airoldi et al. 2015). Many marine NIS disperse following a "huband-spoke" model involving transport hubs (e.g. ports and harbors) and vector transits (e.g. recreational boating) (Carlton 1996; Floerl et al. 2009). Introduction of NIS to transport hubs is often by ship biofouling or ballast water vectors (Hewitt and Campbell 2010) and the associated proliferation of 
docks and other structures expands the space available for colonization. From there, secondary spread via vector transits or self-dispersal promotes range expansion across coastal infrastructure (Bishop et al. 2017) and at times into natural habitats. 'Static' maritime structures ("SMS") are well recognized as pivotal hubs of NIS establishment (Duarte et al. 2013; Airoldi et al. 2015), but are rarely considered as potential vectors themselves. We define SMS as artificial structures that spend a predominant amount of their life span fixed to the seabed or shore, but can be moved in water; examples include offshore energy platforms, obsolete vessels, non-cargo barges, floating buildings and docks, aquaculture gear and buoys.

Critically, movement of static maritime structures is a vastly underappreciated transfer mechanism of marine NIS because a majority of their operational life span is indeed static. SMS are particularly potent vectors of biofouling communities owing to long residence times in one location, where biofouling accumulates, followed by towing at slow speeds to a new location (Davidson et al. 2008a; Yeo et al. 2010; Pajuelo et al. 2016). While both non- and selfpropelled SMS (e.g. semi-submersible platforms and historic vessels) are prone to biofouling, we focused on non-self-propelled SMS as they typically fall outside of maritime industry biofouling regulations. Independent case studies have reported SMS as vectors of NIS spread (e.g. Foster and Willan 1979; DeFelice 1999; Godwin 2003; Wanless et al. 2010; Casoli et al. 2016), yet these structures are not part of a broader vector management discussion and are generally overlooked compared to shipping, boating and aquaculture vectors (Ruiz et al. 2011). It is increasingly clear that movement of SMS is a prevalent and high-risk vector of NIS spread that warrants more attention for effective coastal resource management.

We evaluated the spatial extent and movement of SMS and their association with marine NIS richness across the Northeast Pacific coast from 47 to $59^{\circ} \mathrm{N}$ (Washington, USA north across British Columbia, Canada to Southeast Alaska, USA) and related this to examples at the global scale. We compiled and mapped (1) the 'standing stock' of each structure category in the region, (2) case studies of structure movements and tracked towing vessel pathways and (3) the distribution of NIS richness across the coastline. We further documented the extent of biotic transfer associated with floating dock movements through surveys of biofouling communities before and after dock towing events. To our knowledge, movements of SMS have not been collated and quantified for any region to-date, perhaps owing to the lack of centralized reporting of such movements. As such, we used standing stock, in addition to movement case studies, to characterize the amount of SMS with potential to move, as all of these structures will be moved into and out of water, or across water, for reasons including operation, trade, or disposal at the end of their effective life span. The intersection between sprawling growth of SMS and NIS colonization and spread on these structures is a global invasion concern and a driver of coastal change in the Anthropocene.

\section{Methods}

SMS spatial extent, movement, and NIS richness

We compiled geolocations of floating structures using online and government datasets, as well as the most recent satellite images on Google Earth for floating derelict vessels, buildings and docks, aquaculture gear and buoys (see Appendix S1 Table S1 for all data sources). Floating buildings (lodges, homes and work sheds) and docks are those that extend onto seawater but are not on fixed pilings above water level (i.e. they rise and fall with tides). Floating buildings were counted as distinct structures unless they were part of an aquaculture facility. Dock locations were binned into size categories, with small docks and associated marina structures grouped together as 'marina areas' based on spatial clustering and a visual estimate of size on Google Earth (haphazard selection, $\mathrm{n}=35$ per category). Navigational buoys were included, but mooring buoys, which are abundant in coastal waters, were not included here as we were unable to verify their locations.

Examples of floating structure pathways were collated through grey literature, online news articles, questionnaires and community outreach for the structures listed above as well as for oil platforms and obsolete vessels (Appendix S1 Table S1). We also used automatic ship identification of tug and towing vessels from terrestrial receivers as a proxy of towed item (non-cargo barge and dry dock) movements that occurred throughout 2016. 
NIS locational records were aggregated (every $3+$ sites within $20 \mathrm{~km}$ ) and richness was mapped at the centroid of the spatial extent collated, with outlying points mapped individually (ArcGIS v. 10.4). Although marine taxa vary in their likelihood of transfer via fouling vectors, we included all taxa because highly mobile species frequently inhabit the dense biofouling matrices that develop on floating structures (Wanless et al. 2010; Pajuelo et al. 2016).

\section{Towed dock surveys}

We examined biotic transfers, including NIS, via dock movements around Vancouver Island, British Columbia by conducting photo surveys of the underside of four docks ("D1-4") before and after towing events, and video recording the underside of a dock during towing ("D3"). We identified the proportion of biofouling that was relocated, the change in species composition pre- and post-towing, and visible taxa that fell off during towing (see Appendix S2 for survey details). The influence of dock identity (i.e. D1-D4) and pre/post-towing on biofouling cover and bare space were analyzed additively using a generalized linear model ("GLM") with a binomial distribution and Tukey's post hoc tests. Biofouling communities were visually compared with non-metric multidimensional scaling ("NMDS") using Jaccard dissimilarity and significant differences were tested with Permutational Analysis of Variance ("PERMANOVA").

\section{Results}

\section{Spatial extent of SMS and NIS}

We mapped 9800 geolocations of SMS spanning the NE Pacific (Fig. 1, Table 1). In particular, floating docks covered an estimated area of $2.3 \mathrm{~km}^{2}$ (Fig. 2), with a linear distance of dock surface equivalent to $3 \%$ of the length of our study region's coastline (i.e. $2265.7 \mathrm{~km}$ by $1 \mathrm{~m}$ ). In addition, there were records for 138 marine NIS, which represents $48 \%$ of the total reported for western North America (California to Alaska; Ruiz et al. 2011). A majority of the NIS were recorded from artificial structures or settlement plates suspended from those structures, and all have the potential to occur within biofouling communities and be transferred during translocation events (Gartner et al. 2016; Fofonoff et al. 2018).

\section{Movement of SMS}

We found 34 examples of SMS pathways and hundreds of towing events, with structure types exhibiting different movement patterns, scales and reasons for movement (Fig. 2, Table 1). We recorded two cases of oil platforms that were stationed in Puget Sound, Washington for up to a month before being towed to Arctic Alaskan coastlines for exploratory drilling operations (Fig. 2a, Appendix S3 Table S1). There were nine high-profile cases of obsoletes (ships, ferries, tug boats) that had been moored in marine locations for 2-6 years, or in one case 30 years where it was used as a lodge, before being towed to a new location (least-cost overwater distance, domestic movements: $125.0 \mathrm{~km} \pm 29.5$; mean $\pm 1 \mathrm{SE}$ ). Four of these were towed to Mexico for scrap ( $>2000 \mathrm{~km}$; Appendix S3 Table S1) (Fig. 2a). In addition, 442 tug and towing vessels were tracked, with $57 \%$ crossing national borders (Fig. 2c). We further found that 12 of 31 floating lodges for which we received information move seasonally within Canada's waters (Table 1), frequently overwintering in more populated destinations and, in some cases, traversing the length of the coastline (294.2 km \pm 104.2) (Fig. 2, Appendix S3 Table S2). We also recorded 12 cases of floating docks towed in-water to new locations, often between bays but within regions (23.8 $\mathrm{km} \pm 7.2$ ) (Fig. 2, Appendix S3 Table S3). Four of 22 shellfish growers in Canada from whom we received information, as well as two major finfish companies, described localized movements of gear based on production cycles (Table 1). We did not find any cases of purposeful movement of buoys.

\section{Ecosystem transplants via dock movements}

We found that biofouling cover and species composition were more distinct among docks (cover: Tukey's, D1 v. D3: z $=9.98, p<0.001$, D2 v. D3: $\mathrm{z}=11.13, p<0.001$, remaining: $p>0.05$; composition: PERMANOVA, partial $\left.\mathrm{R}^{2}=0.40, \mathrm{p}=0.001\right)$ than before and after towing events (cover: GLM, $\mathrm{z}=2.17, \quad p=0.03$; composition: PERMANOVA, partial $\mathrm{R}^{2}=0.01, p=0.08$ ) (Fig. 3a, b). Biofouling consistently covered more than $75 \%$ of the submerged 

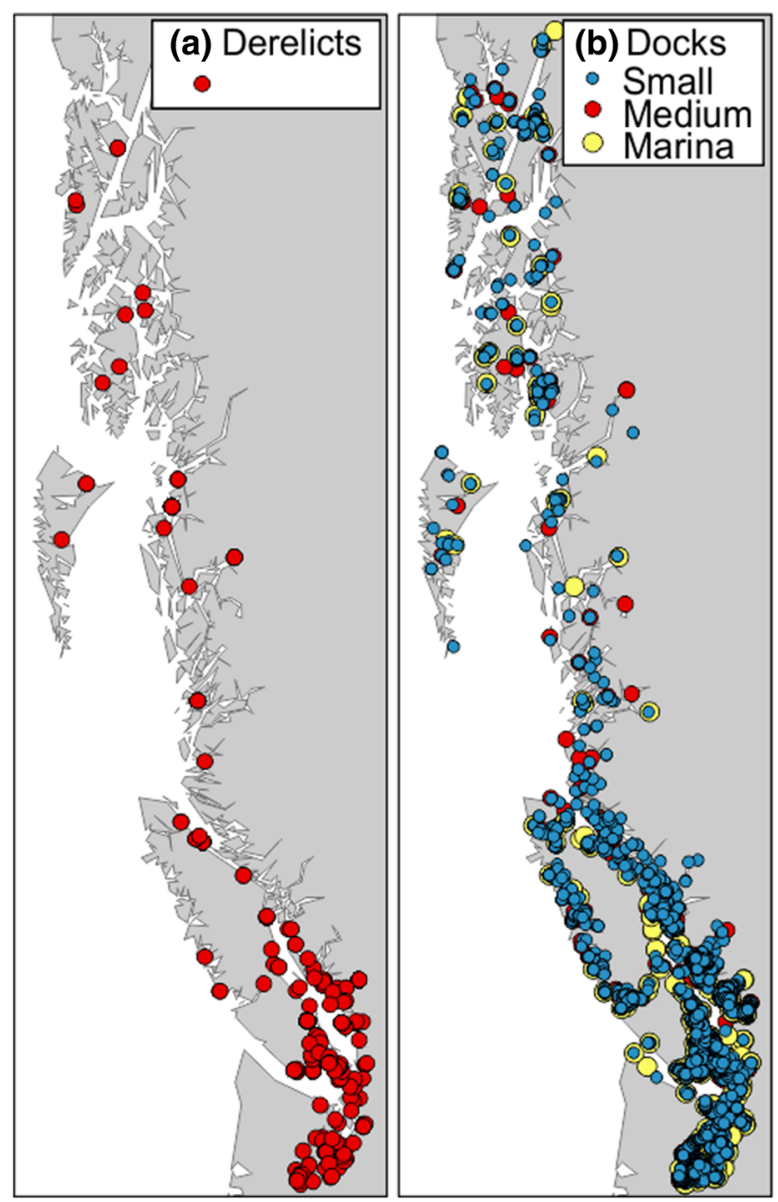

Fig. 1 Standing stock of static maritime structures along the NE Pacific coast for a derelict vessels, b moveable docks categorized by size (small: $57.2 \mathrm{~m}^{2} \pm 6.7$, medium:

float space, with a slight decline following towing for D2 and D3, and maintenance of $100 \%$ cover for D4. Unattached, drift organisms (green algae Ulva, rockweed Fucus and eelgrass Zostera marina) and attached organisms (sea anemone Metridium, sponge Halichondria, hydrozoan and mussel Mytilus trossulus clumps) dislodged from D3 during the towing event (Fig. 3c). Dislodgement was particularly high in the first 30 min of towing, and declined after 2 h. Nonnative botryllid tunicates (Botrylloides violaceus or Botryllus schlosseri) were present on three of the docks following towing, and on the fourth dock (D2) prior to towing.

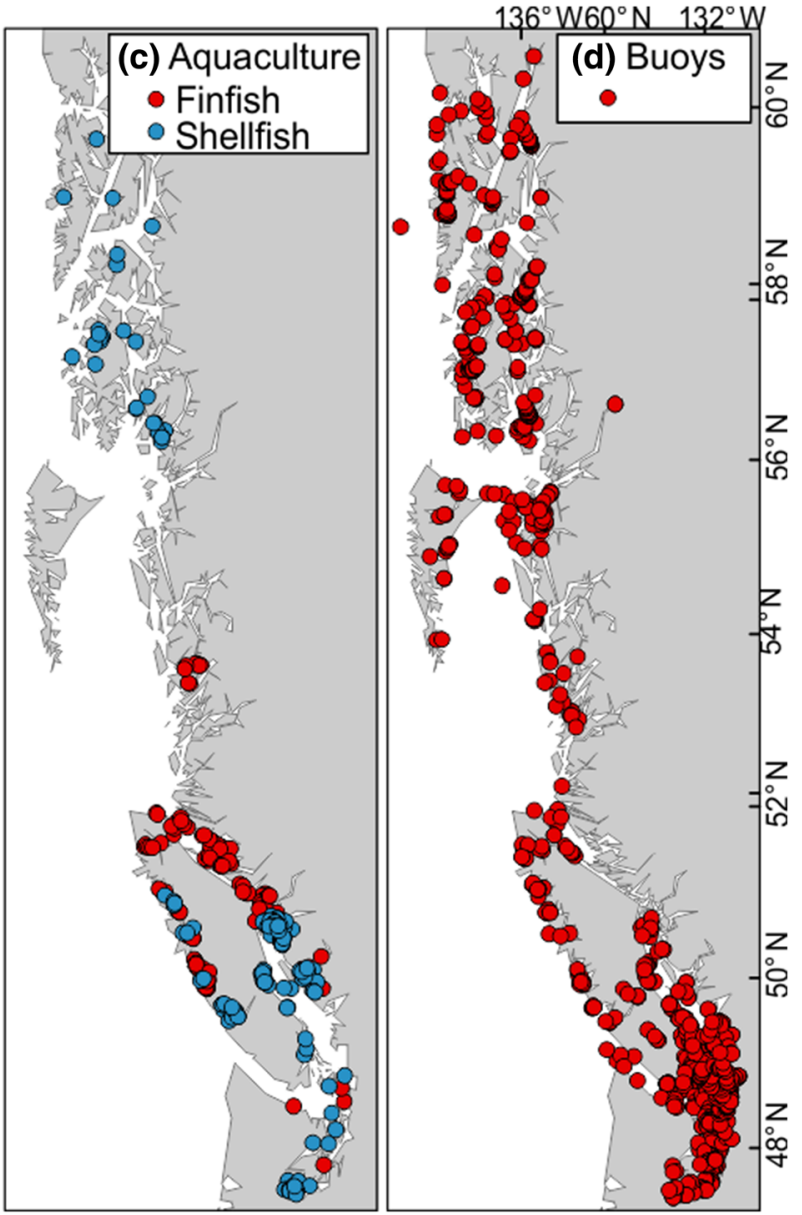

$379.1 \mathrm{~m}^{2} \pm 42.8$, marina area: $4453.5 \mathrm{~m}^{2} \pm 744.4 ; \mathrm{n}=35$ per category; mean $\pm 1 \mathrm{SE}$ ), $\mathbf{c}$ aquaculture gear and $\mathbf{d}$ navigational buoys

\section{Discussion}

Coastal and offshore development proliferates artificial, standardized structures across coastlines that are prone to biofouling by nonindigenous species. Marine floating structures are predominately static during their operational lifespan, but we show that towing of these structures is not uncommon. Long stationary periods followed by slow towing events provide an exceptional opportunity for ecosystem transplants and unwanted introductions, as presented here, and found at a global scale (Table 2). Movement of SMS is largely unreported and unregulated, yet presents a biosecurity issue that requires inclusion in vector management research and policies. 
Table 1 Number ("no.") and movement characteristics of static maritime structures along the NE Pacific coast. Movement case studies and details are from grey literature and online news articles (energy platforms, obsolete vessels), questionnaires (fishing lodges, aquaculture gear), community and government communication (docks, fishing lodges and buoys), and ship tracking systems (non-cargo barges, dry docks). Structures that are higher-risk invasion vectors are in bold

\begin{tabular}{|c|c|c|c|c|c|}
\hline Structure & No. of structures & $\begin{array}{l}\text { No. of } \\
\text { movement } \\
\text { cases (yr range) }\end{array}$ & $\begin{array}{l}\text { Movement } \\
\text { pattern }\end{array}$ & $\begin{array}{l}\text { Movement } \\
\text { scale }\end{array}$ & Movement reasons \\
\hline $\begin{array}{l}\text { Offshore energy } \\
\text { platforms }\end{array}$ & 1200 globally & $2(2012-2015)$ & Stochastic & International & $\begin{array}{l}\text { Set-up and tow for deployment, } \\
\text { seasonal storage, relocation }\end{array}$ \\
\hline $\begin{array}{l}\text { Derelict and } \\
\text { obsolete vessels }\end{array}$ & 379 & 9 (2011-2016) & Stochastic & $\begin{array}{l}\text { International, } \\
\text { national, } \\
\text { local }\end{array}$ & $\begin{array}{l}\text { Sale/scrapping, relocation from } \\
\text { high-risk area, drifting }\end{array}$ \\
\hline $\begin{array}{l}\text { Non-cargo barges, } \\
\text { dry docks }\end{array}$ & $\begin{array}{l}442 \text { tug and towing } \\
\text { vessels as proxy }\end{array}$ & 442 (2016) & $\begin{array}{l}\text { Stochastic, } \\
\text { seasonal }\end{array}$ & $\begin{array}{l}\text { International, } \\
\text { national, } \\
\text { local }\end{array}$ & $\begin{array}{l}\text { Construction, logging, marine } \\
\text { infrastructure } \\
\text { relocation/maintenance }\end{array}$ \\
\hline $\begin{array}{l}\text { Fishing lodges, } \\
\text { resorts; floating } \\
\text { buildings }\end{array}$ & $35 ; 335$ & $\begin{array}{l}12 \text { of } 31 \\
\text { responses } \\
(2017) ; \mathrm{n} / \mathrm{a}\end{array}$ & Seasonal & $\begin{array}{l}\text { National, } \\
\text { local }\end{array}$ & $\begin{array}{l}\text { Seasonal storage, } \\
\text { decommissioning }\end{array}$ \\
\hline Docks & $\begin{array}{l}7809 \text { (small: } 6562, \\
\text { medium: } 899, \text { marina } \\
\text { area: } 348 \text { ) }\end{array}$ & 12 (2016-2017) & $\begin{array}{l}\text { Stochastic, } \\
\text { seasonal }\end{array}$ & Local & $\begin{array}{l}\text { Renovations, seasonal storage, } \\
\text { decommissioning }\end{array}$ \\
\hline $\begin{array}{l}\text { Finfish gear and } \\
\text { workfloats }\end{array}$ & 123 operations & $\begin{array}{l}2 \text { major } \\
\text { companies } \\
(2017)\end{array}$ & Seasonal & Local & $\begin{array}{l}\text { Cycling among tenures every } \\
\text { few years, or for changes in } \\
\text { equipment }\end{array}$ \\
\hline $\begin{array}{l}\text { Shellfish gear } \\
\text { (subtidal and } \\
\text { suspended) }\end{array}$ & 184 operations & $\begin{array}{l}4 \text { of } 22 \\
\text { responses } \\
(2017)\end{array}$ & $\begin{array}{c}\text { Stochastic, } \\
\text { seasonal }\end{array}$ & Local & $\begin{array}{l}\text { Grow out cycles and market } \\
\text { sales, repair or disposal }\end{array}$ \\
\hline Navigational buoys & 879 & $\begin{array}{l}\text { See reasons } \\
\text { column }\end{array}$ & None & $\begin{array}{l}\text { See reasons } \\
\text { column }\end{array}$ & $\begin{array}{l}\text { Only moved if drifted from set } \\
\text { location }\end{array}$ \\
\hline
\end{tabular}

\section{SMS movement attributes}

Among all categories of SMS, offshore energy platforms have the highest incidence of long-distance transfers globally, with frequent coastwise, transocean and inter-ocean movements. There are currently 1200 oil drilling units worldwide, most of which are non-self-propelled and towed at slow speeds (i.e. not including drillships; www.rigzone.com/oil/data/ offshore-rig-search/, viewed 12/2017) (Table 1). Oil platforms facilitate the spread of very large aggregations of biofouling, including assemblages of NIS (Foster and Willan 1979), nonindigenous fishes and other mobile taxa that utilize biofouling matrices as habitat (Wanless et al. 2010; Yeo et al. 2010; Pajuelo et al. 2016).

Derelicts and obsoletes often remain moored for a long period of time during the transition from functioning vessels to floating structures, which marks the end of any regular biofouling management that accompanied 'vessel' status. They may then be towed to multiple locations to await removal, with larger vessels frequently towed internationally to be recycled (Wan et al. 2016). Obsoletes have transferred live NIS despite undergoing month-long, inter-ocean towing across steep gradients of temperature and salinity (Davidson et al. 2008a). Derelicts and obsoletes are a worldwide environmental problem often passed down a chain of decreasing regulatory oversight with concentrated ship scrapping in India, Bangladesh, Pakistan (Hossain 2015) and Mexico (shown here) (Wan et al. 2016). Historic maritime vessels pose a similar invasion risk as they are towed or selfpropelled globally at slow speeds for restoration, relocation (Apte et al. 2000) and goodwill tours (Carlton and Hodder 1995).

Barges, dry docks and maritime construction equipment have been recorded as heavily fouled prior 
Fig. 2 Spatial extent and movement pathways of static maritime structures, and nonindigenous species richness (yellow

proportional bubbles) for the NE Pacific coast (main map and $\mathbf{a}-\mathbf{b}$ insets). Locations of floating structures are represented for dock area (density interpolation; red gradient) and buildings (lodges/homes, turquoise squares); movement case studies (lines) are for oil platforms (purple), obsolete vessels (blue), floating lodges (dark turquoise), and floating docks (dark red).

c Tug and towing pathways represent in part movement of non-cargo barges and dry docks that transit within (Canada: dark purple lines; USA orange lines) and across national borders (light blue lines; Canada Exclusive Economic Zone, yellow shaded area)

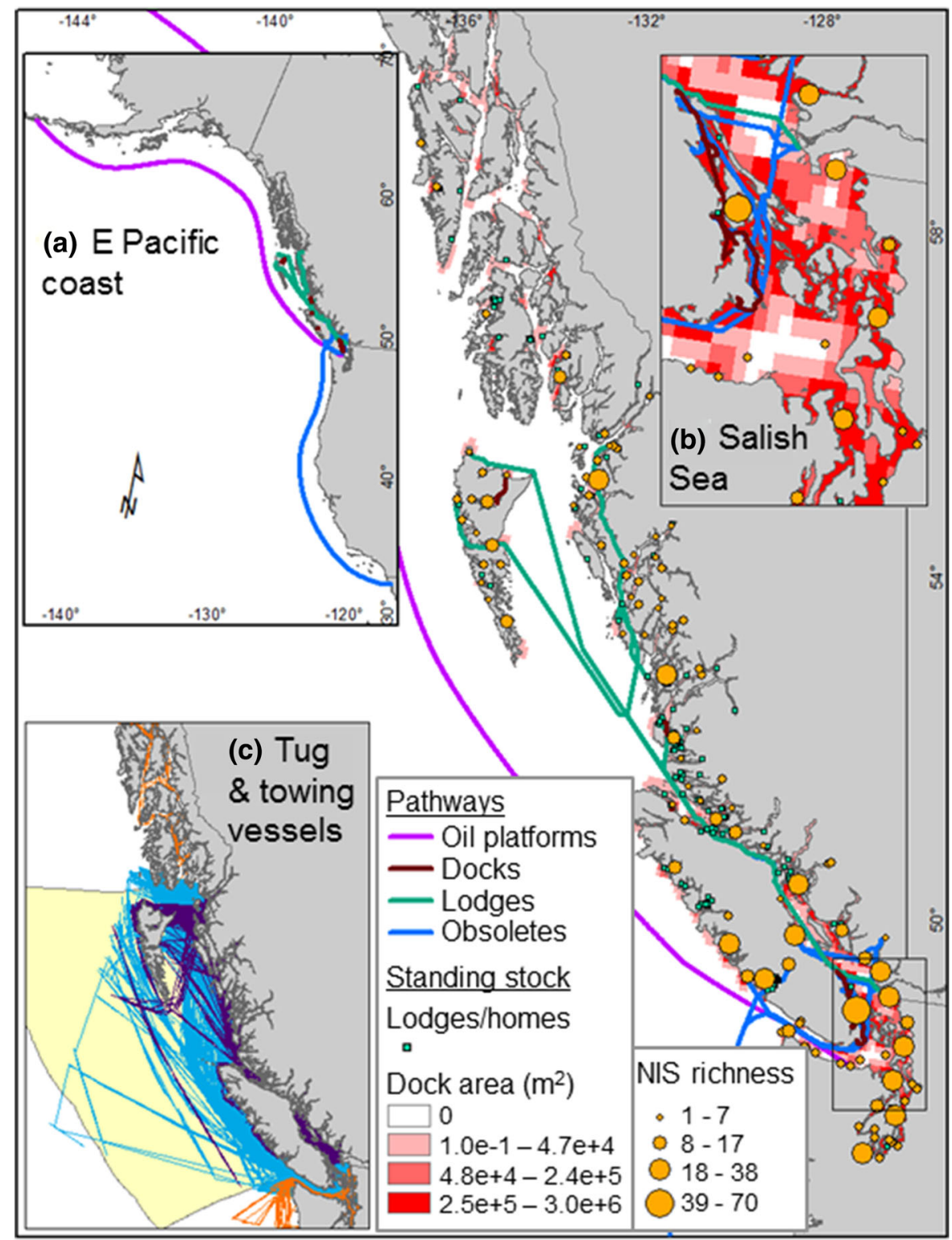

to towing internationally and nationally, with the potential for introduction and spread of NIS (DeFelice 1999; Godwin 2003; Lewis et al. 2006). Cargo barges are subject to biofouling management guidelines, though maritime industry standards of low fouling levels can still pose an invasion risk (Godwin 2003). Floating fishing lodges and resorts often operate in remote areas and may be more prevalent in our study region than many others throughout the world. However, floating docks are a conspicuous component of urbanized coastlines and a primary driver of sprawling artificial surface area in bays and estuaries.
Nonindigenous tunicates have been recorded on dock floats more than any other sampled substrate worldwide (Simkanin et al. 2012). Furthermore, our dock survey results unequivocally demonstrate that most biota, including NIS, is retained during dock towing events. These results align with larger scale towing events that maintained high levels of community biomass and richness upon relocation (e.g. Davidson et al. 2008a; Yeo et al. 2010; Table 2).

Aquaculture production had a long history as a primary vector of NIS introduction (Naylor et al. 2001), although changing industry practice and 


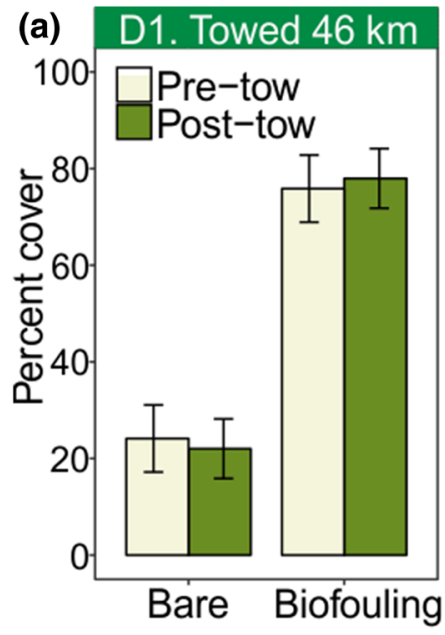

(b)

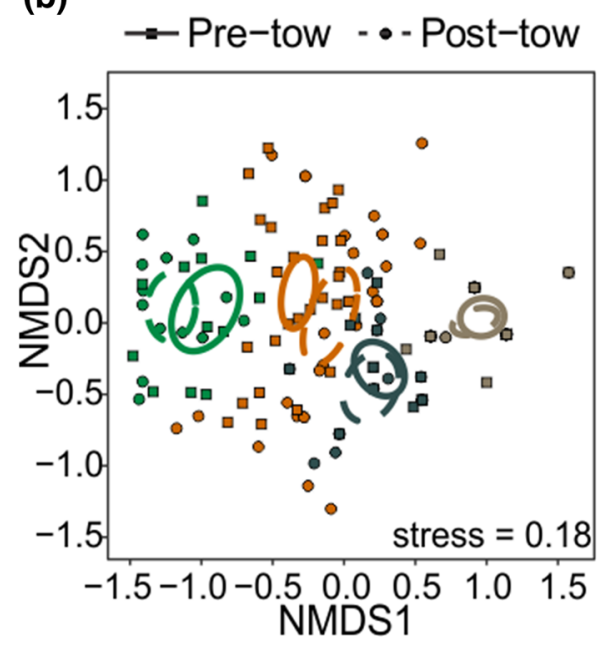

Fig. 3 Floating dock surveys ("D1-4") showed minimal change in a percent cover of bare and biofouled float surface ("pre-tow": off-white bars; "post-tow": olive-green bars), as well as similarity in b fouling species before (solid lines and squares) and after towing events (dashed lines and circles) (dock colour-coding matches in [a] and [b]). c Seven taxonomic

regulation have subsequently reduced its vector potential (Grosholz et al. 2015). Aquaculture infrastructure and gear are second only to floating docks in recorded incidence of nonindigenous tunicate biofouling (Simkanin et al. 2012). We found that aquaculture gear is an unlikely vector for the NE Pacific because of limited movement of shellfish gear and existing cleaning practices that are mandated for finfish aquaculture. However, unreported selling of gear may occur, and other regions may differ in aquaculture practices such that gear should not be fully disregarded as a vector. Finally, although buoys are rarely
D3. Towed $11 \mathrm{~km} \quad$ D4. Towed $2 \mathrm{~km}$

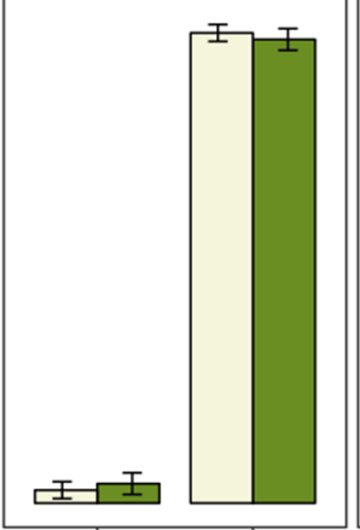

Bare Biofouling

(c)

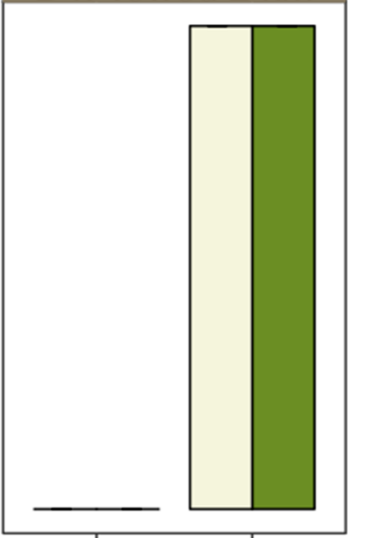

Bare Biofouling

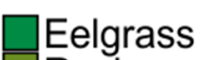
Rockweed Mussel clump

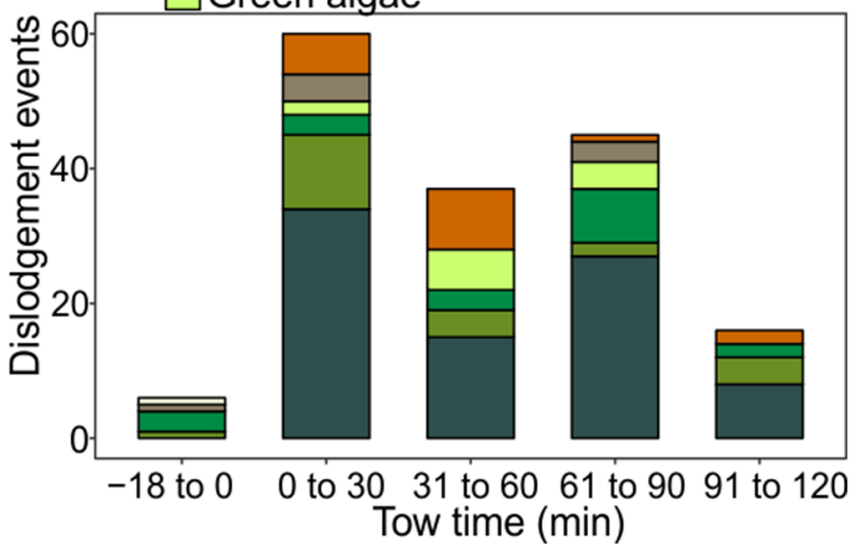

groups were visibly identified to dislodge during an experimental dock towing (D3), including drift species that were unattached (green algae Ulva, rockweed Fucus, eelgrass Zostera) and attached species (sea anemone Metridium, sponge Halichondria, hydrozoan, mussel Mytilus clumps and associated unidentified taxa)

repositioned intentionally, some that have been relocated or detached and drifted have been found to host NIS (Astudillo et al. 2009; Carlton et al. 2011).

SMS vector and pathway characteristics

All SMS have a potential for 'ecosystem transplant' when they move. Biofouling NIS may disperse during transit or upon arrival at a new location by fragmentation, detachment or spawning, though slow towing movements of floating structures $(\leq 10 \mathrm{~km} / \mathrm{h}$ ) enables intact communities to be directly introduced (Coutts 
Table 2 Global examples of ecosystem transplants following intentional (realized or planned) relocation of non-self-propelled static maritime structures

\begin{tabular}{|c|c|c|c|c|}
\hline Structure & Origin & Destination & $\begin{array}{l}\text { Live biofouling found } \\
\text { upon relocation }\end{array}$ & References \\
\hline Oil platform & Japan & New Zealand & Yes & Foster and Willan (1979) \\
\hline $\begin{array}{l}\text { Oil platform, } \\
\text { decommissioned }\end{array}$ & Brazil & $\begin{array}{l}\text { Tristan da Cunha, } \\
\text { BOT }\end{array}$ & Yes & Wanless et al. (2010) \\
\hline Oil platform & $\begin{array}{l}\text { Various locations, South } \\
\text { China Sea most recent }\end{array}$ & Singapore & Yes & Yeo et al. (2010) \\
\hline Obsolete vessel & Washington, USA & Hawaii, USA & Yes & Apte et al. (2000) \\
\hline Obsolete vessels (2) & California, USA & Texas, USA & Yes & Davidson et al. (2008a) \\
\hline Dry dock & Hawaii, USA & Guam, USA & $\begin{array}{l}\text { Live biofouling } \\
\text { surveyed before } \\
\text { towing }\end{array}$ & DeFelice (1999) \\
\hline $\begin{array}{l}\text { Dry dock and cargo } \\
\text { barges }(7)\end{array}$ & $\begin{array}{l}\text { W, E, and NE Central } \\
\text { Pacific }\end{array}$ & Hawaii, USA & Yes & Godwin (2003) \\
\hline Barge & Tasmania, Australia & $\begin{array}{l}\text { To be brought to } \\
\text { Macquarie Island, } \\
\text { Australia, } \\
\text { subantarctic aboard } \\
\text { ship and deployed }\end{array}$ & $\begin{array}{l}\text { Live biofouling } \\
\text { surveyed before } \\
\text { towing, deployment } \\
\text { canceled in light of } \\
\text { invasion risk }\end{array}$ & Lewis et al. (2006) \\
\hline Barges (2) & England & Giglio Island, Italy & $\begin{array}{l}\text { Yes, but extinction } \\
1 \text { yr later }\end{array}$ & Casoli et al. (2016) \\
\hline
\end{tabular}

et al. 2010). The tour of a historic sailing vessel into bays and estuaries along the west coast of the United States transported a largely intact biofouling community with extensive detachment of hydroid polyps that had the potential to disperse into isolated bays (Carlton and Hodder 1995). Spawning can also be triggered by changing water conditions during transit (Minchin and Gollasch 2003), and long residence times of repositioned structures provide ample opportunity for feeding and reproduction at destinations (e.g. 'port renewal hypothesis'; Carlton 1999).

Biofouling communities may experience a gradient of conditions as they are moved along a pathway. They may not survive large shifts in temperature or salinity during transport-in rivers or freshwater canals, for example - or may be relocated to habitats that are more or less suitable. Habitat suitability, including the type of benthic substrate, can also be an important limiting factor for dislodged organisms (Coutts 2002).

Future trends and management

Marine urbanization is globally extensive and static maritime structures continue to proliferate worldwide. SMS vector events represent a small fraction of those by shipping and boating, but they are characterized by high biofouling abundance and diversity, relatively benign transit conditions (slow speeds), negligible or no management actions (e.g. no antifouling remediation) and typically long-term post-transit residency in the recipient region, compared to, for example, transient commercial vessel traffic. Thus, the cumulative effects of their movement may be substantial.

Perpetual maritime development and increasing demand for offshore energy will exacerbate the role of this vector in NIS spread. The NE Pacific coastline does not yet have offshore wind turbines, but these may be a vector in other regions and in future expansion of offshore energy when stationed in coastal waters prior to deployment. Oil rig movements are also expected to increase as Arctic sea ice declines and national policies open more offshore waters for drilling. Increasing coastal infrastructure and associated shipping vectors are predicted to further establish the Arctic as a hub of biotic exchange (Ricciardi et al. 2017). This may lead to northward spread of NIS into the Arctic and inter-ocean introductions via Arctic routes.

Movement of SMS is a key issue that warrants further attention and inclusion in broader vector 
management research and policies going forward. The operational life-span of these structures, including decommissioning, should be considered in a biosecurity context, and movements should be better documented to build comprehensive spatiotemporal records of SMS transfers. However, the complexity of initiating management policy and action should not be underestimated. SMS are owned and operated by a range of entities from local municipalities (e.g. publically owned docks) to national government agencies, as well as from private owners to large multi-national corporations. Thus, stakeholder resources for managing complex environmental externalities are divergent. There is little incentive to maintain clean underwater surfaces on structures primarily designated for static use, although occasional maintenance may be required to improve towing efficiency, water flow or buoyancy of structures. Approaches adopted by other sectors of maritime industry, including anti-fouling and foul-release coatings on vessels, are designed for operational tempos that far exceed the typical movement frequency of structures considered here. Similarly, drydocking or in-water cleaning are not typically undertaken to remove biofouling of the extent found on SMS and may simply be impractical. There is little precedent for managing biofouling on these structures and, therefore, few off-the-shelf solutions to implement at present.

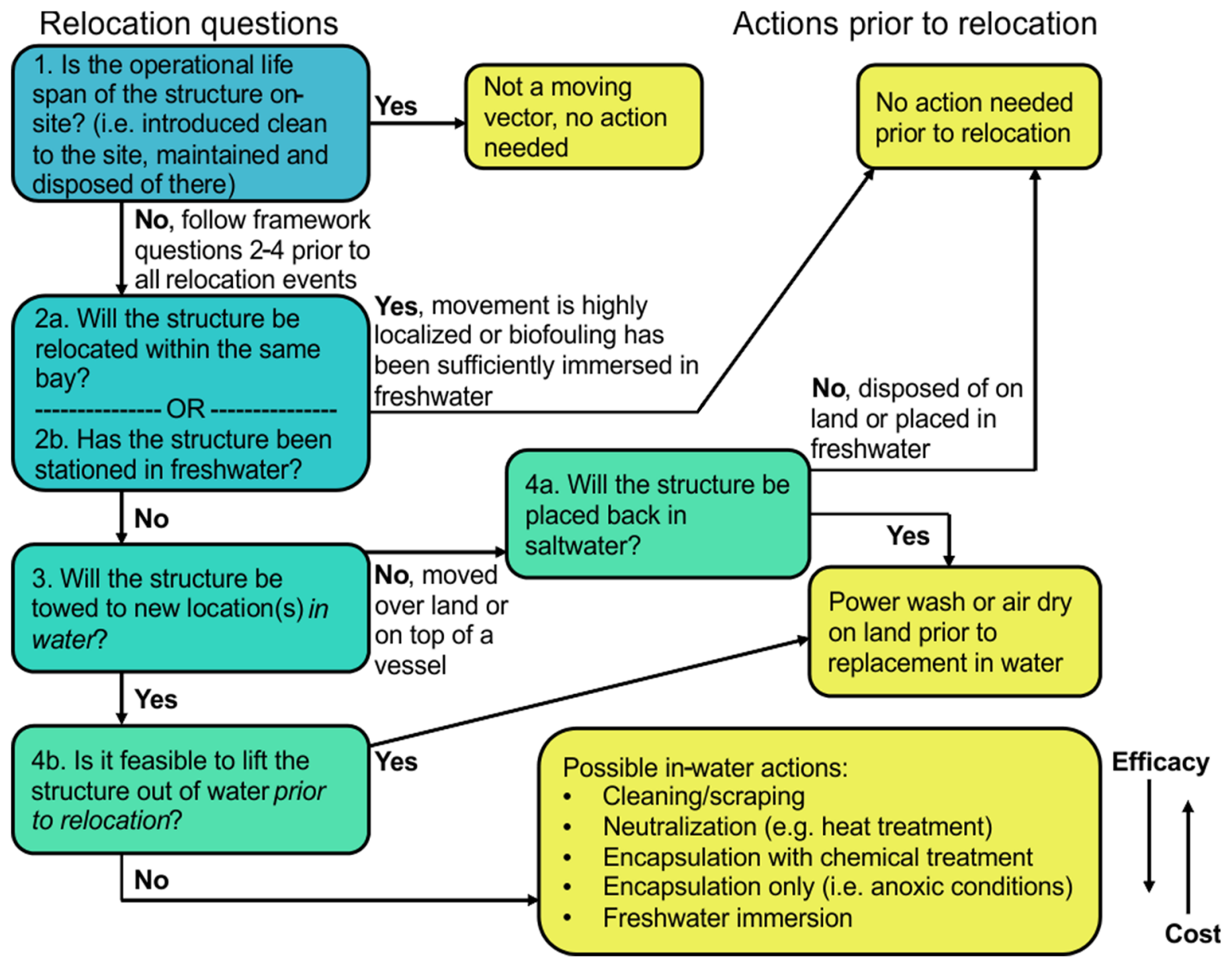

Fig. 4 Conceptual framework for management of nonindigenous species spread through movement of static maritime structures. Actions to effectively remove biofouling (yellow shaded boxes) are based on answers to questions regarding the operation and movement characteristics of the structure (1-4, blue-green shaded boxes). Note, stationing in freshwater requires non-brackish water conditions and a sufficient amount of time to kill biofouling 
Nonetheless, there is growing awareness of the impact of major transfer and invasion events associated with SMS, and examples of management to reduce species translocations have emerged. These include in-water cleaning, in-water treatment (e.g. heat treatment to neutralize biofouling organisms), encapsulation (with possible chemical treatment), temporary repositioning to freshwater sites, haul-out for power washing and air drying, and biological surveys for unwanted NIS or pest species (Wotton et al. 2004; Coutts and Forrest 2007; Davidson et al. 2008b; Atalah et al. 2016). Few jurisdictions have policy frameworks to manage invasion risks from this vector, although New Zealand imposes biofouling thresholds or requires documentation of best-practice husbandry and maintenance for all vessels and SMS entering coastal waters (New Zealand Government 2014).

An initial management framework should consider (a) the type of structure, (b) the frequency or purpose of movement within its operational life span and (c) the range of management actions that have been or can be taken to reduce or prevent species transfers (Fig. 4). Ultimately, coastal infrastructure is likely to remain on its current sprawling trajectory with translocations occurring more often than acknowledged, and thus perhaps explaining the introduction of some species not clearly associated with more familiar vectors. Environmental planning, regulatory incentives, and workable solutions will be needed to promote biosecurity awareness and reduce NIS transfers within and among regions.

Acknowledgements We thank Jaclyn Boutillier and Matthew Stafford for assistance in data collection, Sharon Jeffery for species identification, and Shelley Jepps and Shane Peterson for project discussions and $\mathrm{BC}$ aquaculture data sharing. We greatly appreciate the support of the Marine Spatial Ecology and Analysis Section of Fisheries and Oceans Canada (DFO) in conducting dock surveys. We also thank J. Carlton and anonymous reviewers for insightful comments. Funding was provided by DFO Strategic Program for Ecosystem-based Research and Advice (JCI and AD) and the Smithsonian Institution (ICD).

Open Access This article is distributed under the terms of the Creative Commons Attribution 4.0 International License (http:// creativecommons.org/licenses/by/4.0/), which permits unrestricted use, distribution, and reproduction in any medium, provided you give appropriate credit to the original author(s) and the source, provide a link to the Creative Commons license, and indicate if changes were made.

\section{References}

Airoldi L, Turon X, Perkol-Finkel S, Rius M (2015) Corridors for aliens but not for natives: effects of marine urban sprawl at a regional scale. Divers Distrib 21:755-768. https://doi. org/10.1111/ddi.12301

Apte, S, Holland BS, Godwin S, Gardner JPA (2000) Jumping ship: a stepping stone event mediating transfer of a nonindigenous species via a potentially unsuitable environment. Biol Invasions 2:75-79

Astudillo JC, Bravo M, Dumont CP, Thiel M (2009) Detached aquaculture buoys in the SE Pacific: potential dispersal vehicles for associated organisms. Aquat Biol 5:219-231

Atalah J, Brook R, Cahill P, Fletcher LM, Hopkins GA (2016) It's a wrap: encapsulation as a management tool for marine biofouling. Biofouling 32:277-286. https://doi.org/10. 1080/08927014.2015.1137288

Bishop MJ, Mayer-Pinto M, Airoldi L, Firth LB, Morris RL, Loke LHL et al (2017) Effects of ocean sprawl on ecological connectivity: impacts and solutions. J Exp Mar Biol Ecol 492:7-30. https://doi.org/10.1016/j.jembe.2017.01. 021

Carlton JT (1996) Pattern, process, and prediction in marine invasion ecology. Biol Conserv 78:97-106. https://doi.org/ 10.1016/0006-3207(96)00020-1

Carlton JT (1999) The scale and ecological consequences of biological invasions in the world's oceans. In: Sandlund OT, Schei PJ, Viken A (eds) Invasive species and biodiversity management. Kluwer Academic Publishers, Dordrecht

Carlton JT, Hodder J (1995) Biogeography and dispersal of coastal marine organisms: experimental studies on a replica of a 16th-century sailing vessel. Mar Biol 121:721-730. https://doi.org/10.1007/bf00349308

Carlton JT, Newman WA, Pitombo FB (2011) Barnacle invasions: introduced, cryptogenic, and range expanding Cirripedia of North and South America. In: Galil BS, Clark PF, Carlton JT (eds) In the wrong place-alien marine crustaceans: Distribution, biology and impacts. Invading nature-Springer series in invasion ecology. Springer, Dordrecht

Casoli E, Ventura D, Modica MV, Belluscio A, Capello M, Oliverio M, Ardizzone GD (2016) A massive ingression of the alien species Mytilus edulis L. (Bivalvia: Mollusca) into the Mediterranean Sea following the Costa Concordia cruise-ship distaster. Meditter Mar Sci 17:404-416. https:// doi.org/10.12681/mms. 1619

Coutts ADM (2002) A biosecurity investigation of a barge in the Marlborough Sounds. Cawthron Report No. 744. Cawthron Institute, Nelson, p 744

Coutts ADM, Forrest BM (2007) Development and application of tools for incursion response: lessons learned from the management of the fouling pest Didemnum vexillum. J Exp Mar Biol Ecol 342:154-162. https://doi.org/10.1016/j. jembe.2006.10.042

Coutts ADM, Piola RF, Hewitt CL, Connell SD, Gardner JPA (2010) Effect of vessel voyage speed on survival of biofouling organisms: implications for translocation of nonindigenous marine species. Biofouling 26:1-13. https:// doi.org/10.1080/08927010903174599 
Davidson IC, McCann LD, Fofonoff PW, Systma MD, Ruiz GM (2008a) The potential for hull-mediated species transfers by obsolete ships on their final voyages. Divers Distrib 14:518-529. https://doi.org/10.1111/j.1472-4642.2008. 00465.x

Davidson IC, McCann LD, Sytsma MD, Ruiz GM (2008b) Interrupting a multi-species bioinvasion vector: the efficacy of in-water cleaning for removing biofouling on obsolete vessels. Mar Pollut Bull 56:1538-1544. https:// doi.org/10.1016/j.marpolbul.2008.05.024

DeFelice RC (1999) Fouling marine invertebrates on the floating dry dock USS Machinist in Pearl Harbor prior to its move to Apra Harbor, Guam. Contribution No. 1999-013. Hawaii Biological Survey, Honolulu

Duarte CM, Pitt KA, Lucas CH, Purcell JE, Uye S, Robinson K et al (2013) Is global ocean sprawl a cause of jellyfish blooms? Front Ecol Environ 11:91-97. https://doi.org/10. $1890 / 110246$

Firth LB, Knights AM, Bridger D, Evans AJ, Mieszkowska N, Moore PJ et al (2016) Ocean sprawl: challenges and opportunities for biodiversity management in a changing world. Oceanogr Mar Biol 54:193-269

Floerl O, Inglis GJ, Dey K, Smith A (2009) The importance of transport hubs in stepping-stone invasions. J Appl Ecol 46:37-45. https://doi.org/10.1111/j.1365-2664.2008. 01540.x

Fofonoff PW, Ruiz GM, Steves B, Simkanin C, Carlton JT (2018) National exotic marine and esuarine species information system. http://invasions.si.edu/nemesis. Viewed 16 Feb 2018

Foster BA, Willan RC (1979) Foreign barnacles transported to New Zealand on an oil platform. N Z J Mar Fresh 13:143-149. https://doi.org/10.1080/00288330.1979. 9515788

Gartner HN, Clarke Murray C, Frey MA, Nelson JC, Larson KJ, Ruiz GM, Therriault TW (2016) Non-indigenous invertebrate species in the marine fouling communities of British Columbia, Canada. BioInvasions Rec 5:205-212

Godwin LS (2003) Hull fouling of maritime vessels as a pathway for marine species invasions to the Hawaiian Islands. Biofouling 19(Suppl):123-131. https://doi.org/10.1080/ 0892701031000061750

Grosholz ED, Crafton RE, Fontana RE, Pasari JR, Williams SL, Zabin CJ (2015) Aquaculture as a vector for marine invasions in California. Biol Invasions 17:1471-1484. https:// doi.org/10.1007/s10530-014-0808-9

Hewitt CL, Campbell ML (2010) The relative contribution of vectors to the introduction and translocation of invasive marine species. Department of Agriculture, Fisheries and Forestry, Canberra. ISBN 978-1-921575-14-3

Hossain KA (2015) Overview of ship recycling industry of Bangladesh. J Environ Anal Toxicol 5:312. https://doi.org/ 10.4172/2161-0525.1000312
Lewis PN, Bergstrom DM, Whinam J (2006) Barging in: a temperate marine community travels to the Subantarctic. Biol Invasions 8:787-795. https://doi.org/10.1007/s10530005-3837-6

Minchin D, Gollasch S (2003) Fouling and ships' hulls: how changing circumstances and spawning events may result in the spread of exotic species. Biofouling 19(Suppl):111-122. https://doi.org/10.1080/ 0892701021000057891

Naylor RL, Williams SL, Strong DR (2001) Aquaculture-a gateway for exotic species. Science 294:1655-1656. https://doi.org/10.1126/science.1064875

New Zealand Government (2014) Craft risk management standard: biofouling of vessels arriving to New Zealand. Biosecurity New Zealand, Ministry of Primary Industries, Wellington

Pajuelo JG, González JA, Triay-Portella R, Martín JA, RuizDíaz R, Lorenzo JM, Luque A (2016) Introduction of nonnative marine fish species to the Canary Islands waters through oil platforms as vectors. J Mar Syst 163:23-30. https://doi.org/10.1016/j.jmarsys.2016.06.008

Ricciardi A, Blackburn TM, Carlton JT, Dick JTA, Hulme PE, Iacarella JC et al (2017) Invasion science: a horizon scan of emerging challenges and opportunities. Trends Ecol Evol 32:464-474. https://doi.org/10.1016/j.tree.2017.03.007

Ruiz GM, Fofonoff PW, Steves B, Foss SF, Shiba SN (2011) Marine invasion history and vector analysis of California: a hotspot for western North America. Divers Distrib 17:362-373. https://doi.org/10.1111/j.1472-4642.2011. 00742.x

Simkanin C, Davidson IC, Dower JF, Jamieson G, Therriault TW (2012) Anthropogenic structures and the infiltration of natural benthos by invasive ascidians. Mar Ecol 33:499-511. https://doi.org/10.1111/j.1439-0485.2012. 00516.x

Wan Z, Zhu M, Chen S, Sperling D (2016) Pollution: three steps to a green shipping industry. Nature 530:275-277. https:// doi.org/10.1038/530275a

Wanless RM, Scott S, Sauer WHH, Andrew TG, Glass JP, Godfrey B et al (2010) Semi-submersible rigs: a vector transporting entire marine communities around the world. Biol Invasions 12:2573-2583. https://doi.org/10.1007/ s10530-009-9666-2

Wotton DM, O'Brien C, Stuart MD, Fergus DJ (2004) Eradication success down under: heat treatment of a sunken trawler to kill the invasive seaweed Undaria pinnatifida. Mar Pollut Bull 49:844-849. https://doi.org/10.1016/j. marpolbul.2004.05.001

Yeo DC, Ahyong ST, Lodge DM, Ng PK, Lane DJ (2010) Semisubmersible oil platforms: understudied and potentially major vectors of biofouling-mediated invasions. Biofouling 26:179-186. https://doi.org/10.1080/ 08927010903402438 